Original Article

\title{
Toxicological effects of thimerosal on rat kidney: a histological and biochemical study
}

\author{
Efeitos toxicológicos do timerosal no rim de rato: um estudo histológico e bioquímico
}

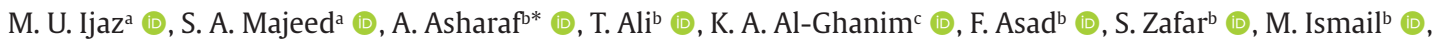 \\ A. Samad ${ }^{\text {(D) }, ~ Z . ~ A h m e d ~}{ }^{b}$ (D), F. Al-Misnedc (D), M. N. Riaz ${ }^{d}$ and S. Mahboobc ${ }^{*}$ (D) \\ aUniversity of Agriculture, Department of Zoology, Wildlife and Fisheries, Faisalabad, Pakistan \\ ${ }^{\mathrm{b}}$ Government College University, Department of Zoology, Faisalabad, Pakistan \\ cKing Saud University, Department of Zoology, College of Science, Riyadh, Saudi Arabia. \\ dTexas A\&M University, AMU, Brazos, Texas, United States of America
}

\begin{abstract}
Thimerosal is an organomercurial compound, which is used in the preparation of intramuscular immunoglobulin, antivenoms, tattoo inks, skin test antigens, nasal products, ophthalmic drops, and vaccines as a preservative. In most of animal species and humans, the kidney is one of the main sites for mercurial compounds deposition and target organs for toxicity. So, the current research was intended to assess the thimerosal induced nephrotoxicity in male rats. Twenty-four adult male albino rats were categorized into four groups. The first group was a control group. Rats of Group-II, Group-III, and Group-IV were administered with $0.5 \mu \mathrm{g} / \mathrm{kg}, 10 \mu \mathrm{g} / \mathrm{kg}$, and $50 \mu \mathrm{g} / \mathrm{kg}$ of thimerosal once a day, respectively. Thimerosal administration significantly decreased the activities of catalase (CAT), superoxide dismutase (SOD), peroxidase (POD), glutathione reductase (GR), glutathione (GSH), and protein content while increased the thiobarbituric acid reactive substances (TBARS) and hydrogen peroxide $\left(\mathrm{H}_{2} \mathrm{O}_{2}\right)$ levels dose-dependently. Blood urea nitrogen (BUN), creatinine, urobilinogen, urinary proteins, kidney injury molecule-1 (KIM-1), and neutrophil gelatinase-associated lipocalin (NGAL) levels were substantially increased. In contrast, urinary albumin and creatinine clearance was reduced dose-dependently in thimerosal treated groups. The results demonstrated that thimerosal significantly increased the inflammation indicators including nuclear factor kappaB (NF- $\kappa$ B), tumor necrosis factor- $\alpha$ (TNF- $\alpha$ ), Interleukin-1 $\beta$ (IL-1 $\beta$ ), Interleukin- 6 (IL-6) levels and cyclooxygenase-2 (COX-2) activities, DNA and histopathological damages dose-dependently. So, the present findings ascertained that thimerosal exerted nephrotoxicity in male albino rats.
\end{abstract}

Keywords: Thimerosal, Organomercurial, inflammation, Nephrotoxicity.

\section{Resumo}

O timerosal é um composto organomercurial, utilizado na preparação de imunoglobulina intramuscular, antivenenos, tintas de tatuagem, antígenos de teste cutâneo, produtos nasais, gotas oftálmicas e vacinas como conservante. Na maioria das espécies animais e nos humanos, o rim é um dos principais locais de deposição de compostos de mercúrio e órgãos-alvo de toxicidade. Assim, a presente pesquisa teve como objetivo avaliar a nefrotoxicidade induzida pelo timerosal em ratos machos. Vinte e quatro ratos albinos machos adultos foram categorizados em quatro grupos. O primeiro grupo era um grupo de controle. Ratos do Grupo II, Grupo III e Grupo IV receberam 0,5 $\mathrm{gg} / \mathrm{kg}, 10 \mu \mathrm{g} / \mathrm{kg}$ e $50 \mu \mathrm{g} / \mathrm{kg}$ de timerosal uma vez ao dia, respectivamente. A administração de timerosal diminuiu significativamente as atividades de catalase (CAT), superóxido dismutase (SOD), peroxidase (POD), glutationa redutase (GR), glutationa (GSH) e conteúdo de proteína, enquanto aumentou as substâncias reativas ao ácido tiobarbitúrico (TBARS) e peróxido de hidrogênio $\left(\mathrm{H}_{2} \mathrm{O}_{2}\right)$ níveis dependentes da dose. Os níveis de nitrogênio ureico no sangue (BUN), creatinina, urobilinogênio, proteínas urinárias, molécula de lesão renal-1 (KIM-1) e lipocalina associada à gelatinase de neutrófilos (NGAL) aumentaram substancialmente. Em contraste, a albumina urinária e a depuração da creatinina foram reduzidas de forma dependente da dose nos grupos tratados com timerosal. Os resultados demonstraram que o timerosal aumentou significativamente os indicadores de inflamação, incluindo fator nuclear kappaB (NF- $\kappa \mathrm{B})$, fator de necrose tumoral- $\alpha$ (TNF- $\alpha$ ), interleucina- $1 \beta$ (IL-1 $\beta$ ), níveis de interleucina-6 (IL-6) e atividades da ciclooxigenase-2 (COX-2), DNA e danos histopatológicos dependentes da dose. Portanto, os presentes achados verificaram que o timerosal exerceu nefrotoxicidade em ratos albinos machos.

Palavras-chave: Timerosal, Organomercurial, inflamação, Nefrotoxicidade.

*e-mail: mushahid@ksu.edu.sa; asmabinm@gmail.com

Received: August 30, 2020 - Accepted: February 17, 2021 


\section{Introduction}

The bioaccumulation ability of heavy metals is an issue of major concern (Sharaf et al., 2020). Mercury (Hg) is a persistent bio-accumulative toxic heavy metal with unique physicochemical properties of public health concern since their natural and anthropogenic diffusions still induce high risk to human and environmental health (Bjørklund et al., 2017). Mercury is present in the environment (Nabil et al., 2020) in different forms; inorganic mercury, organic mercury, and metallic or elemental mercuric compounds (Park and Zheng, 2012). It is an extremely toxic element that quickly disturbs the cardiovascular and nervous systems. Vomiting, diarrhea, severe kidney damage, and nausea may occur due to exposure to high doses of mercury, even for a short interval. Memory loss, hallucinations, inability to concentrate, and nerve damage can also appear (Ekawanti and Krisnayanti, 2015). Mercuric and Mercurous salts primarily injure the kidney, gut lining, and get circulated throughout the entire body. Toxicity depends upon dosage: elemental mercury vapor exposure induces acute pneumonitis, which can be deadly in severe cases (Berlin et al., 2007).

Ethylmercury thiosalicylate (thimerosal) is the most common form of organomercurials (DÓREA et al., 2013). Thimerosal is an antifungal and antibacterial mercurycontaining compound which is used in vaccine and biological product as a preservative (Ball et al., 2001). Thimerosal has been used in preparations of intramuscular immunoglobulin, antivenoms, tattoo inks, skin test antigens, nasal products, and vaccines as a preservative (Counter and Buchanan, 2004). Hg is present in thimerosal ( $49.6 \%$ by weight) and produces Et-Hg (ethylmercury) in the form of metabolite. This metabolite (EtHg) then changes into inorganic $\mathrm{Hg}$ in the body, which accumulates in the brain and kidneys (Tan and Parkin, 2000). Few studies have established the relationship between neurodevelopmental arrangement and exposure to mercury through vaccination (Yel et al., 2005; Herman et al., 2006).

Thimerosal dissociates into thiosalicylic acid and the ethylmercury cation in the aqueous media due to the hydrolysis equilibrium reaction (Trümpler et al., 2009). Initial risk estimations for et-Hg were established based on oral toxicity studies of me-Hg due to the deficiency of evidence about the thimerosal behavior in the mammalian body. However, the fresh data point out that the metabolism and kinetics of tissue disposition considerably differ between the et-Hg and me-Hg (Burbacher et al., 2014), representing that methyl-mercury is not an appropriate testimonial for the risk evaluation of thimerosal. The possible harmful health effects of thimerosal have not yet been sufficiently investigated. So, the present study was designed and performed to evaluate the possible harmful effects of thimerosal on the rat kidney.

\section{Materials and Methods}

\subsection{Chemicals}

Thimerosal was bought from the Fisher Scientific-United States of America.

\subsection{Animals}

Adult male wistar rats (180-200 g), were used for the research trial. Rats were placed in the animal house at $24 \pm 2{ }^{\circ} \mathrm{C}$ for 30 days. Dark/light cycle ( $12 \mathrm{~h}$.) was maintained. Rats were fed with proper food and tap water. The experimental animals (rats) were kept in the primate facility of the animal house of the University of Agriculture Faisalabad. Rats were cared for and treated in compliance with animal handling guidelines.

\subsection{Experimental design}

Adult male albino rats (24) were divided into four equivalent groups ( $n=6 /$ group). Group 1: This group was taken as control and given intramuscular (i.m.) injection of normal saline on day 1,11 and 21 of treatment. Group 2: $0.5 \mu \mathrm{g} / \mathrm{kg}$ dose of thimerosal dissolved in normal saline was given to this group via i.m. injection on day $1,11$ and 21 of the trial. Group 3-( $n=6)$ : This group was treated with $10 \mu \mathrm{g} / \mathrm{kg}$ i.m. dose of thimerosal dissolved in normal saline on day 1, 11 and 21 of treatment. Group 4-(n=6) received i.m. injection of $50 \mu \mathrm{g} / \mathrm{kg}$ of thimerosal dissolved in normal saline on day 1, 11 and 21 of treatment.

The total trial duration was 30 days. After the completion of the trial, all rats were anesthetized and slaughtered after 24 hours of the last treatment. Blood samples were collected into the sterile tubes from all the animals in each group. Blood samples were centrifuged at $3000 \mathrm{rpm}$ for 15 minutes; then, plasma was removed and stored at $-20^{\circ} \mathrm{C}$ for further study. Saline was used to washing out the kidney. The right kidney was packed in small zipper bags and these bags were stored soon after dissection at $-80^{\circ} \mathrm{C}$ for antioxidant enzymes analysis.

\subsection{Biochemical assays}

The kidney was stored at $-80^{\circ} \mathrm{C}$ and homogenized in $3 \mathrm{ml}$ of PBS ( $\mathrm{pH} 7.4$ ), then centrifuged for 15 minutes at $12000 \mathrm{rpm}$ before analysis. The resultant supernatant was utilized for the analysis of the antioxidant enzyme. Chance and Maehly (1955) procedure was trailed for the determination of CAT and POD activities. Absorbance changes in the mixture were checked at $240 \mathrm{~nm}$ and its final values were shown as $\mathrm{U} / \mathrm{mg}$ protein. The activity of SOD was assayed by noticing the change in color intensity (at $560 \mathrm{~nm}$ ), by Kakkar et al. (1948). The values of SOD activity were presented as unit/mg protein. GSH content was measured by pursuing the procedure of Jollow et al. (1974), using 1,2-dithio-bis nitro benzoic acid (DTNB) as substrate. The yellow color developed was read immediately at $412 \mathrm{~nm}$ and expressed as $\mathrm{nM} / \mathrm{min} / \mathrm{mg}$ protein. The GR activity was calculated by computing NADPH disappearance at about $340 \mathrm{~nm}$ by procedure of Carlberg and Mannervik (1975). Total protein content was assessed by following the protocol of Lowry et al. (1951). TBARS level was measured by following the protocol of Qbal et al. (1996), at $535 \mathrm{~nm}$ by using 2-thiobarbituric acid (2,6-dihydroxypyrimidine-2-thiol; TBA). The results were expressed as $\mathrm{nM} / \mathrm{min} / \mathrm{mg}$ protein. To evaluate the quantity of $\mathrm{H}_{2} \mathrm{O}_{2}$, the protocol introduced by Pick and Keisari (1981) was followed. 


\subsection{Assessment of DNA damage through Comet assay}

The comet parameters were estimated by using assay specified by Dhawan et al. (2009). Firstly, tissues of the kidney were washed with phosphate buffer saline (PBS) and dehydrated quickly $\left(37^{\circ} \mathrm{C}\right)$. Autoclaved slides were smeared with $1 \%$ regular melting point agarose $(100 \mu \mathrm{l})$ and protected with a coverslip and kept at low temp. $\left(4^{\circ} \mathrm{C}\right)$ for hardening. A small renal tissue' section was kept in the chilled $1 \mathrm{~mL}$ lysis solution; then, following homogenization, it was mixed with the $75 \mu$ low melting point agarose (LMA). Pre-coated slides were smeared in this mixture again, overlaid and solidified by putting slides on ice-cubes for about $10 \mathrm{~min}$. After the third layer of agarose, slides were put in a lysing buffer for about 10 minutes and placed on ice-cubes for 2 hours. Then these slides were kept in the electrophoresiscolumns containing a neutral buffer. Gel-electrophoresis was performed. Electrophoresis was carried out at $25 \mathrm{~V}$ for twenty minutes; then slides were dehydrated at $5^{\circ} \mathrm{C}$, then again re-hydrated and stained with $1 \%$ ethidium-bromide to inspect under a fluorescent microscope (400X). For the evaluation of the total comet score 50 to 100 cells from each slide were observed and CASP 1.23.B (software) was used for assessing the comet parameters.

\subsection{Kidney function markers}

With the help of standard diagnostic kits (AMEDA labordiagnostic Gmbh, Austria), estimation of albumin, urea, urobilinogen, creatinine, urinary proteins, and creatinine clearance was completed. Urinary KIM-1 and Serum NGAL were determined according to the manufacturer's command by using KIM-1 Quantikine ELISA Kit and NGAL Quantikine ELISA Kit (R and D Systems China Co. Ltd., Changning, China).

\subsection{Inflammatory markers assessment}

The kidney was stored at $-80{ }^{\circ} \mathrm{C}$ and homogenized in $3 \mathrm{ml}$ of PBS (pH 7.4), then centrifuged at $12000 \mathrm{rpm}$ for 15 minutes before analysis. Commercially available kits were used to assess the inflammatory markers of the renal tissues. NF- $\kappa B$, TNF- $\alpha$, IL-1 $\beta$, IL-6 levels, and COX-2 activity were determined with rat ELISA kit (Shanghai YL Biotech Co. Ltd., China). Analyses were accomplished by following the manufacturer's instructions through Elisa Plate Reader (BioTek, Winooski, VT, USA).

\subsection{Histopathological examination}

Histopathology of the renal tissues was carried out by following the method of Ibrahim et al. (2018). For histopathological analysis, a fixative having absolute alcohol $(60 \mathrm{ml})$, Glacial acetic acid $(10 \mathrm{ml})$, and formaldehyde $(30 \mathrm{ml})$ were utilized to fix the renal tissues. For the preparation of slides, $5 \mu \mathrm{m}$ thin sections of fresh kidney tissues were used. For staining purposes, the hematoxylin-eosin stain was used, and images were taken at a magnification of $40 \mathrm{X}$ under a compound microscope for histopathological study (Nikon, 187842, Japan).

\subsection{Statistical analysis}

The data values were shown as the Mean \pm SEM. Oneway analysis of variance (ANOVA), Dunnett's test was applied to compare different groups by using Minitab software. Differences showing $\mathrm{p}<0.05$ were considered as statistically significant.

\section{Results}

\subsection{Effects of thimerosal on biochemical parameters}

In the present study, significant $(\mathrm{p}<0.05)$ decrease in the activities of CAT, POD, SOD, GR, and GSH content was observed in thimerosal intoxicated groups in contrast to the control group (Figure 1). Protein content was also substantially $(\mathrm{p}<0.05)$ reduced in thimerosal administered groups while substantial $(\mathrm{p}<0.05)$ increase in TBARS and $\mathrm{H}_{2} \mathrm{O}_{2}$ levels were observed in thimerosal treated groups dose-dependently in comparison to control group (Figure 2).

\subsection{Effect of thimerosal on comet parameters}

In this study, DNA damage in renal tissues of thimerosal treated albino rats was assessed with the help of comet assay. In thimerosal treated groups, II, III and IV significant $(p<0.05)$ elevation in the number of comets, comet length, tail length, \% DNA in the tail, tail moment and olive moment was observed while significant $(\mathrm{p}<0.05)$ reduction in $\%$ DNA in head and the head length was detected in renal cells in contrast to control group (Table 1, Figure 3).

\subsection{Effects of thimerosal on BUN and creatinine, albumin, urobilinogen, urinary protein, creatinine clearance, KIM-1, and NGAL}

Thimerosal administration significantly $(\mathrm{p}<0.05)$ elevated the levels of BUN, urinary creatinine, urobilinogen, urinary proteins, KIM-1, and NGAL while reduced urinary albumin and creatinine clearance in treated groups when compared with control (Table 2). Changes in these parameters occurred in dose-dependent manner.

\subsection{Effect of thimerosal on inflammatory markers}

Thimerosal administration substantially $(\mathrm{p}<0.05)$ raised the levels of inflammatory parameters NF- $\kappa \mathrm{B}, \mathrm{TNF}-\alpha$, IL$1 \beta$, IL-6, and COX-2 activities in treated rats in contrast to the control group. The rise in the levels of inflammatory parameters was observed in dose-dependent manners (Table 3).

\subsection{Effect of thimerosal on renal histology}

Microscopic analysis of kidney tissues showed that the treatment of rats with thimerosal caused severe damage in renal parenchyma. Capillaries interlinked with tubules were dilated and dilation of tubules was noticed in the inner medulla. Thimerosal made some tubular distention in the cortex and pivotal epithelial cell damage throughout constrained areas, while in the outer medulla, it persuaded chronic and noticeable cytolysis of epithelial cells. Thimerosal administration increased the tissue damage in dose-dependent manners in treated rats (Figure 4). 

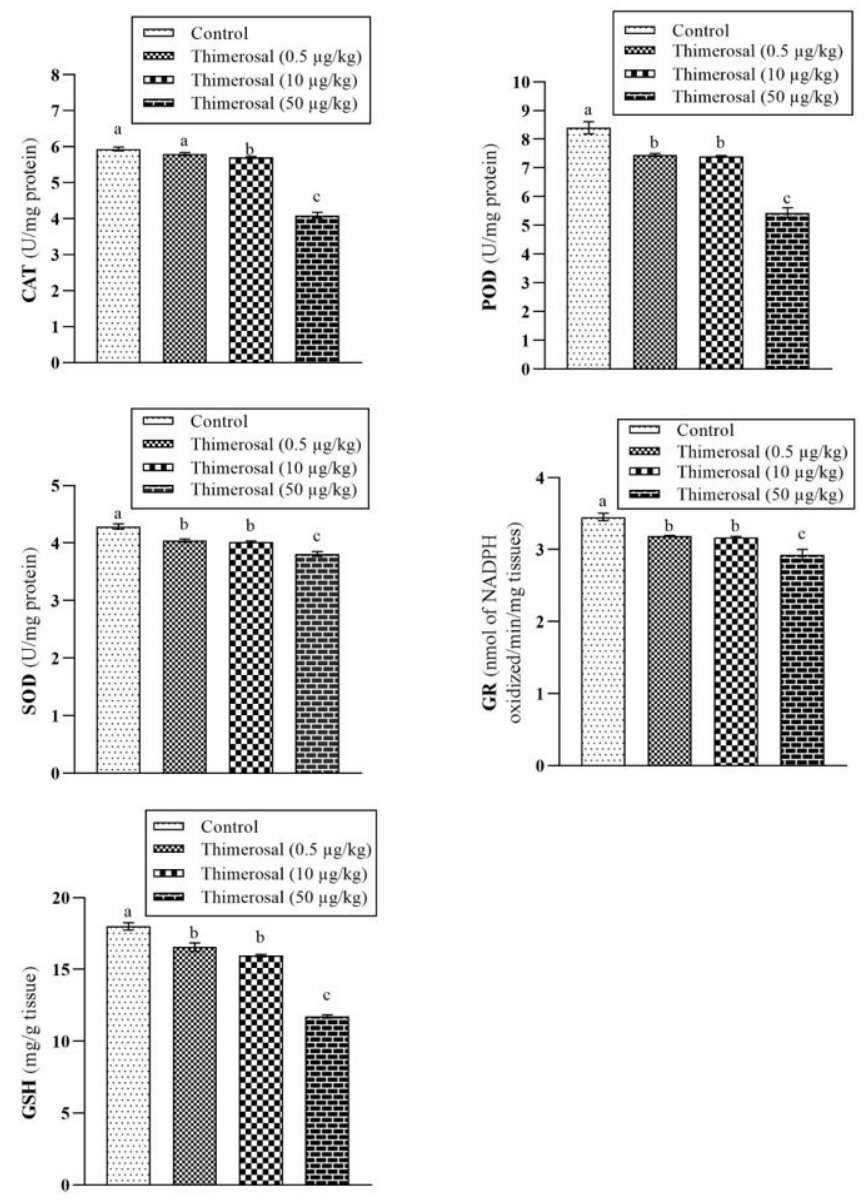

Figure 1. Effects of thimerosal on antioxidant enzymes (CAT, POD, SOD and GR) and GSH content in the kidney. Groups are expressed with different bars. Bars in a same graph having different superscripts are significantly $(\mathrm{p}<0.05)$ different from others.
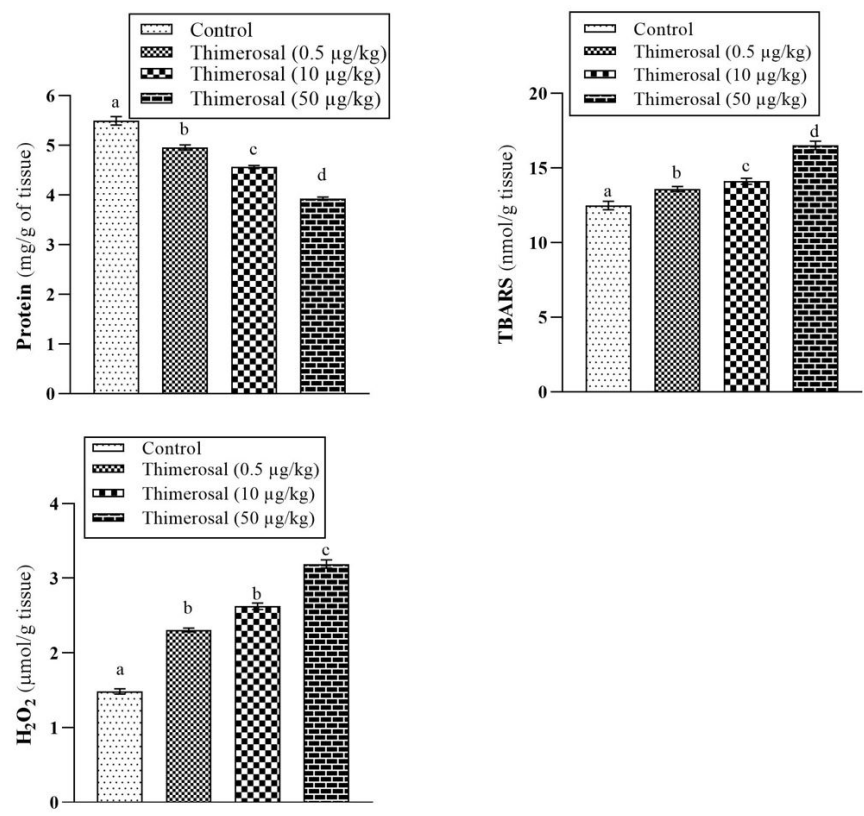

Figure 2. Effects of thimerosal on Protein content, TBARS and $\mathrm{H}_{2} \mathrm{O}_{2}$ levels. Groups are expressed with different bars. Bars in a same graph having different superscripts are significantly $(\mathrm{p}<0.05)$ different from others. 

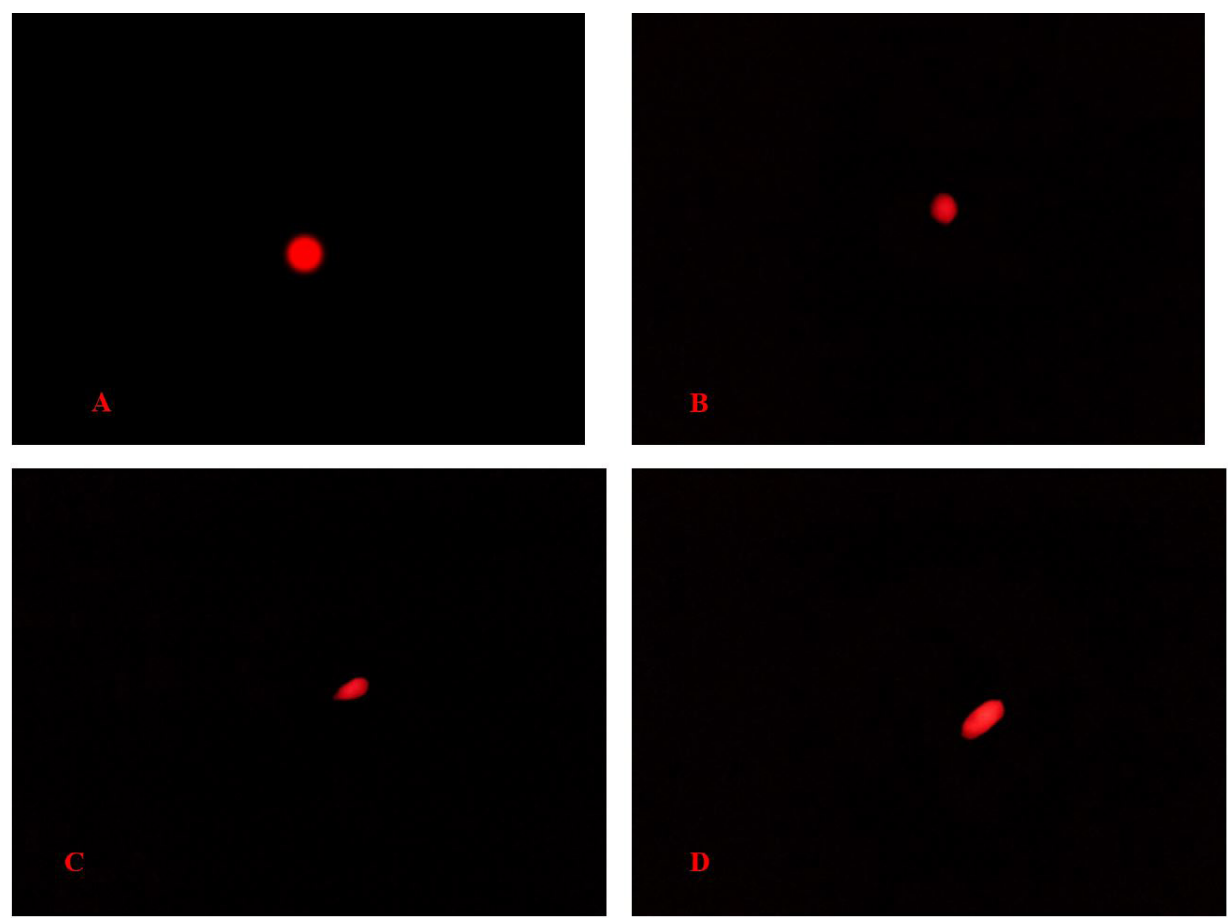

Figure 3. Fluorescence photomicrograph of renal comets and genotoxic outcome of thimerosal (A) Control (B) Thimerosal $(0.5 \mu \mathrm{g} / \mathrm{kg})$ treated $(\mathbf{C})$ Thimerosal $(10 \mu \mathrm{g} / \mathrm{kg})$ treated $(\mathbf{D})$ Thimerosal $(50 \mu \mathrm{g} / \mathrm{kg})$ treated. $400 \mathrm{X}$.

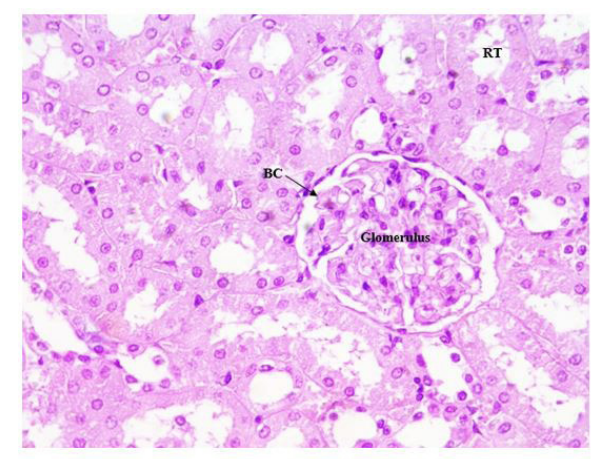

(A) Control

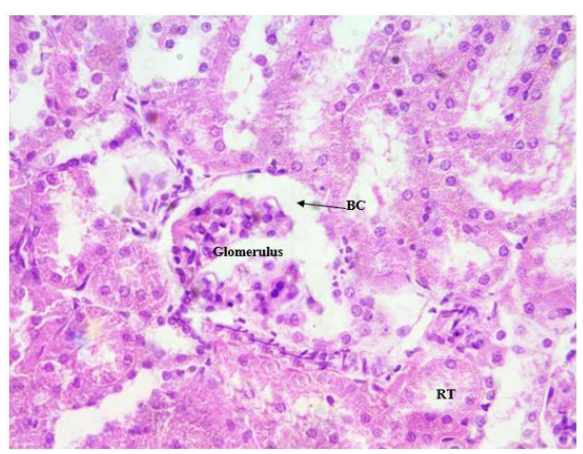

(C) Thimerosal $(10 \mu \mathrm{g} / \mathrm{kg})$

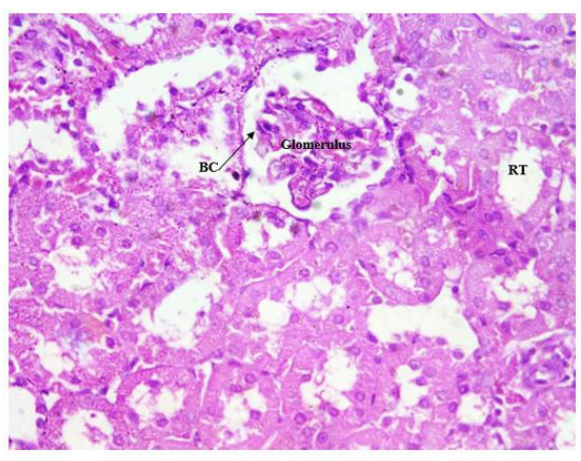

(B) Thimerosal $(0.5 \mu \mathrm{g} / \mathrm{kg})$

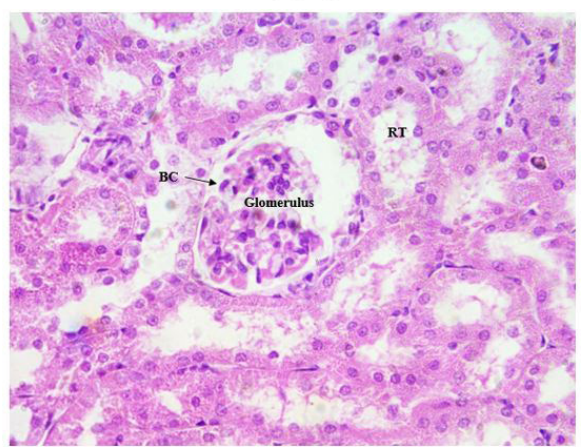

(D) Thimerosal $(50 \mu \mathrm{g} / \mathrm{kg})$

Figure 4. Renal histopathological analysis of the various groups: (A) a microphotograph of kidney section of control group rats, revealing the normal histological structure of glomeruli and renal tubules.; (B) a microphotograph of kidney section of thimerosal ( $0.5 \mathrm{mg} / \mathrm{kg})$ administered rats displaying degenerative changes in renal epithelium and granular deposits in their lumens (C); a microphotograph of thimerosal ( $10 \mathrm{mg} / \mathrm{kg}$ ). (D) a microphotograph of a section of thimerosal $(50 \mathrm{mg} / \mathrm{kg}$ ) treated rats, demonstrating significant degenerative changes, granular deposits in their lumens and desquamation of the kidney epithelium. BC; Bowman's capsule, RT; Renal Tubule. 
Table 1. Effects of thimerosal on comet parameters of kidney.

\begin{tabular}{|c|c|c|c|c|c|c|c|c|}
\hline Groups & $\begin{array}{l}\text { No. of } \\
\text { comets }\end{array}$ & $\begin{array}{l}\text { Comet } \\
\text { length }\end{array}$ & Head length & Tail length & $\%$ in head & $\%$ in tail & $\begin{array}{c}\text { Tail } \\
\text { moment }\end{array}$ & $\begin{array}{c}\text { Olive } \\
\text { moment }\end{array}$ \\
\hline Control & $25.5 \pm 0.28^{a}$ & $39.2 \pm 0.61^{a}$ & $39.6 \pm 0.36^{a}$ & $4.91 \pm 0.24^{a}$ & $94.5 \pm 0.11^{\mathrm{a}}$ & $5.43 \pm 0.11^{\mathrm{a}}$ & $0.89 \pm 0.03^{a}$ & $2.32 \pm 0.05^{\mathrm{a}}$ \\
\hline $\begin{array}{l}\text { Thimerosal } \\
(0.5 \mu \mathrm{g} / \mathrm{kg})\end{array}$ & $30.4 \pm 0.38^{b}$ & $43.7 \pm 0.31^{b}$ & $35.1 \pm 0.24^{b}$ & $6.06 \pm 0.05^{b}$ & $91.0 \pm 0.10^{\mathrm{ab}}$ & $8.96 \pm 0.11^{b}$ & $1.63 \pm 0.04^{b}$ & $2.91 \pm 0.02^{b}$ \\
\hline $\begin{array}{c}\text { Thimerosal } \\
(10 \mu \mathrm{g} / \mathrm{kg})\end{array}$ & $34.5 \pm 2.26^{c}$ & $50.2 \pm 0.59^{c}$ & $34.1 \pm 0.11^{c}$ & $6.65 \pm 0.04^{b}$ & $87.6 \pm 0.26^{b}$ & $12.7 \pm 0.26^{c}$ & $1.88 \pm 0.01^{b}$ & $3.09 \pm 0.03^{b}$ \\
\hline $\begin{array}{l}\text { Thimerosal } \\
(50 \mu \mathrm{g} / \mathrm{kg})\end{array}$ & $46.0 \pm 0.49^{d}$ & $60.0 \pm 0.55^{d}$ & $30.5 \pm 0.26^{d}$ & $8.29 \pm 0.09^{c}$ & $78.1 \pm 0.57^{c}$ & $21.8 \pm 0.57^{d}$ & $2.70 \pm 0.03^{c}$ & $3.61 \pm 0.05^{c}$ \\
\hline
\end{tabular}

Values in a column having disparate superscripts are considerably $(\mathrm{p}<0.05)$ different from others.

Table 2. Effects of thimerosal on the level of BUN, creatinine, creatinine clearance, albumin, urobilinogen, urinary proteins, NGAL, and KIM-1.

\begin{tabular}{ccccc}
\hline Groups & Control & $\begin{array}{c}\text { Thimerosal } \\
(\mathbf{0 . 5} \mu \mathbf{g} / \mathbf{k g})\end{array}$ & $\begin{array}{c}\text { Thimerosal } \\
(\mathbf{1 0} \boldsymbol{\mu g} / \mathbf{k g})\end{array}$ & $\begin{array}{c}\text { Thimerosal } \\
(\mathbf{5 0} \mu \mathbf{g} / \mathbf{k g})\end{array}$ \\
\hline BUN (mg/dl) & $26.21 \pm 0.45^{\mathrm{a}}$ & $32.56 \pm 0.43^{\mathrm{b}}$ & $32.67 \pm 0.44^{\mathrm{b}}$ & $40.63 \pm 0.76^{\mathrm{c}}$ \\
Creatinine (mg/dl) & $0.51 \pm 0.01^{\mathrm{a}}$ & $0.61 \pm 0.01^{\mathrm{b}}$ & $0.63 \pm 0.01^{\mathrm{b}}$ & $0.69 \pm 0.08^{\mathrm{c}}$ \\
Creatinine clearance (ml/min) & $1.74 \pm 0.03^{\mathrm{a}}$ & $1.25 \pm 0.04^{\mathrm{b}}$ & $1.15 \pm 0.03^{\mathrm{bc}}$ & $0.77 \pm 0.05^{\mathrm{c}}$ \\
Albumin (mg/dl) & $8.05 \pm 0.08^{\mathrm{a}}$ & $6.93 \pm 0.13^{\mathrm{b}}$ & $6.73 \pm 0.08^{\mathrm{b}}$ & $5.44 \pm 0.12^{\mathrm{c}}$ \\
Urobilinogen (mg/dl) & $5.52 \pm 0.06^{\mathrm{a}}$ & $5.92 \pm 0.02^{\mathrm{ab}}$ & $6.29 \pm 0.03^{\mathrm{b}}$ & $7.63 \pm 0.04^{\mathrm{c}}$ \\
Urinary protein (mg/dl) & $14.3 \pm 0.06^{\mathrm{a}}$ & $17.0 \pm 0.50^{\mathrm{b}}$ & $18.7 \pm 0.10^{\mathrm{c}}$ & $22.1 \pm 0.20^{\mathrm{d}}$ \\
Urinary KIM-1 (ng/day) & $0.34 \pm 0.04^{\mathrm{a}}$ & $0.86 \pm 0.06^{\mathrm{ab}}$ & $1.23 \pm 0.04^{\mathrm{b}}$ & $1.94 \pm 0.03^{\mathrm{c}}$ \\
NGAL (mg/ml) & $0.69 \pm 0.04^{\mathrm{a}}$ & $1.45 \pm 0.06^{\mathrm{b}}$ & $1.78 \pm 0.05^{\mathrm{bc}}$ & $2.51 \pm 0.11^{\mathrm{c}}$ \\
\hline
\end{tabular}

Values in a row having disparate superscripts are considerably $(\mathrm{p}<0.05)$ different from others.

Table 3. Effects of thimerosal on inflammatory parameters (nuclear factor kappa B (NF- $\kappa$ B), tumor necrosis factor- $\alpha$ (TNF- $\alpha$ ), Interleukin$1 \beta$ (IL-1 $\beta$ ), Interleukin-6 (IL-6) levels and cyclooxygenase-2 (COX-2) activities).

\begin{tabular}{|c|c|c|c|c|c|}
\hline Groups & $\begin{array}{c}\text { NF-кB } \\
\text { (ng/g tissue) }\end{array}$ & $\begin{array}{c}\text { TNF- } \alpha \\
\text { (ng/g tissue) }\end{array}$ & $\begin{array}{c}\text { IL-1及 } \\
\text { (ng/g tissue) }\end{array}$ & IL-6 (ng/g tissue) & $\begin{array}{c}\text { COX-2 } \\
\text { (ng/g tissue) }\end{array}$ \\
\hline Control & $15.1 \pm 0.80^{\mathrm{a}}$ & $7.74 \pm 0.32^{\mathrm{a}}$ & $28.8 \pm 1.64^{\mathrm{a}}$ & $6.05 \pm 0.18^{\text {a }}$ & $31.7 \pm 1.26^{\mathrm{a}}$ \\
\hline Thimerosal $(0.5 \mu \mathrm{g} / \mathrm{kg})$ & $29.2 \pm 0.89^{b}$ & $12.5 \pm 0.36 \mathrm{ab}$ & $68.8 \pm 1.17^{\mathrm{b}}$ & $9.96 \pm 0.22^{b}$ & $44.2 \pm 0.96^{b}$ \\
\hline Thimerosal $(10 \mu \mathrm{g} / \mathrm{kg})$ & $36.2 \pm 0.97^{c}$ & $15.6 \pm 0.54^{b}$ & $86.7 \pm 1.43^{c}$ & $13.4 \pm 0.56^{c}$ & $51.9 \pm 0.79^{c}$ \\
\hline Thimerosal $(50 \mu \mathrm{g} / \mathrm{kg})$ & $57.2 \pm 1.64^{d}$ & $24.2 \pm 0.98^{c}$ & $115.5 \pm 2.46^{\mathrm{d}}$ & $21.3 \pm 0.64^{\mathrm{d}}$ & $65.7 \pm 1.17^{\mathrm{d}}$ \\
\hline
\end{tabular}

Values in a column having disparate superscripts are considerably $(\mathrm{p}<0.05)$ different from others.

\section{Discussion}

In the current analysis, thimerosal treatment showed a considerable decline in antioxidant enzyme activity like CAT, SOD, POD, GR, and GSH and total protein content. In contrast, an astonishing increase in the levels of TBARS and $\mathrm{H}_{2} \mathrm{O}_{2}$ was observed. CAT plays a significant role in the conversion of $\mathrm{H}_{2} \mathrm{O}_{2}$ into $\mathrm{H}_{2} \mathrm{O}$ and $\mathrm{O}_{2}$, therefore protects the cells from the oxidative damage of $\mathrm{H}_{2} \mathrm{O}_{2}$ and $\mathrm{OH}^{-}$(Aitken and Roman, 2008). SOD assists in the conversion of $\mathrm{O}_{2}^{-}$into hydrogen peroxide and $\mathrm{O}_{2}$ (Liochev and Fridovich, 2010). GR oxidizes the glutathione disulfide by transforming it into reduced glutathione (Kaneko et al., 2002). Glutathione (GSH) shields mammalian cells against oxidative stress by minimizing levels of $\mathrm{H}_{2} \mathrm{O}_{2}$ as well as other peroxides (Saleh and Agarwal, 2002; Deponte, 2013). It has been shown that Et-Hg generates oxidative stress by producing hydrogen peroxide, which results in lipid peroxidation
(Mahboob et al., 2001). Mercury produces $\mathrm{H}_{2} \mathrm{O}_{2}$ (Hydrogen peroxide) through multiple reactions. The study of the mechanism demonstrates that mercury disturbs the integrity of the inner membrane of mitochondria, which results in altered membrane potential and ion permeability, causing leakage of $\mathrm{H}_{2} \mathrm{O}_{2}$ (Ercal et al., 2001). Anti-oxidant enzymes, including CAT, SOD, POD, and GR perform a major role in the intracellular defense against cell damages by free radicals (Lobo et al., 2010). A recent study reported that thimerosal administration led to a dose-dependent reduction in the enzyme activities in rat testes (Ijaz et al., 2020). So, it can be speculated that mercury in the Et-Hg is the primary reason behind the increase in oxidative stress, which led to a decrease in antioxidant enzyme activity and increased lipid peroxidation.

The significant alteration was observed in the number of comets, head length, \%DNA in the head, comet length, tail 
length, \% DNA in the tail, tail moment, and olive moment in renal tissues of thimerosal administered groups. Tail length is an indicator of DNA fragmentation evaluated by comet test (Lu et al., 2017). The observed DNA damage in the thimerosal exposed rats can be the result of either DNA oxidation enhancement or the inhibition of the repair system of DNA (Au et al., 2003). Numerous studies have also demonstrated the role of mercury in blocking the DNA repair system (Cebulska-Wasilewska et al., 2005). According to previous literature, thimerosal induced oxidative stress may cause genotoxic effects (Eke and Celik, 2008). Furthermore, Hg compounds can bind directly with the tubulin sulfhydryl, which damages the function of spindle and may cause chromosomal impairments (Vimercati et al., 2001). Our study reported that thimerosal treatment resulted in a significant alteration in comet parameters which shows DNA damaging ability of thimerosal. Moreover, it can be assumed that oxidative stress induced by thimerosal may be a major reason behind the DNA damage.

Kidney damage due to thimerosal exposure was assessed by determining the serum and urinary markers of renal functional integrity, which are the biochemical signs of renal damage. Thimerosal administration elevated the levels of BUN, urinary creatinine, urobilinogen, and urinary proteins while reduced the albumin and creatinine clearance. Increased BUN generally indicates glomerular damage. Whereas, creatinine is a metabolite that is excreted entirely in the urine through glomerular filtration and a rise of its level in the blood is a sign of reduced renal function (Kamianowska et al., 2019). Along with this, the augmented urea, urobilinogen, creatinine, urinary proteins, and decreased albumin, creatinine clearance are the markers for severe oxidative damage to the kidneys (Khan et al., 2010). It has been reported that thimerosal quickly breaks in aqueous saline solutions into Ethyl-Hg chloride (Tan and Parkin, 2000). Trachtenberg et al., 2010 examined in a dose-dependent response study that mercury compounds affect the level of creatinine and it has proved that increased doses of mercury may cause a rise in plasma levels of creatinine. In this study, the concentration of albumin was observed to be decreased after the administration of thimerosal. Decreased albumin excretion is the outcome of glomerular injury; nonetheless, sometimes it is the result of reversible hemodynamic alterations (De La Torre et al., 1998). The excretion of urobilinogen was observed to be increased by thimerosal exposure. In general conditions, urobilinogen is not the component of urine, but its existence in a greater amount in urine is the consequence of thimerosal-induced nephrotoxicity in rats. The creatinine clearance is an authentic indicator of the GFR (glomerular filtration rate). Reduction in creatinine clearance is directly related to reducing the glomerular filtration rate of the animal (Zalups and Diamond, 1987).

Thimerosal administration elevated the levels of KIM- 1 and NGAL in treated rats. KIM- 1 and NGAL are the biomarkers of acute kidney injury (AKI) (Lei et al., 2018). KIM-1 is a transmembrane protein with apparent edges as a new and universally accepted marker for the initial prognosis of AKI (Khan et al., 2012). In the healthy renal tissue, it is nearly not expressed (Arjumand et al., 2011;
Aydin et al., 2011), but it is expressed during the early stages of nephrotoxic injury at mild to elevated levels (Luo et al., 2016). It is also interrelated with the acuteness of renal damage. Additionally, KIM-1 has high stability. It has protein-hydrolytic zones that help to detect its presence in the urine (Lei et al., 2018). NGAL is a modern parameter and is freshly recognized as a member of the lipocalin family (Shin et al., 2009). NGAL is a cytosolic protein that is present in the blood, urine, renal and proximal-distal tubules in the case of nephrotoxicity, kidney parenchymal damage, renal transplant refutation and renal ischemia (Mori et al., 2005). NGAL is expressed in the damaged glomerulus and can persuade epithelial regeneration. It is normally discharged into the blood in greater extents after damage and evacuated through the urine (Ross and Kasum, 2002). In line with previous findings by Zhou et al. (2008) and Luo et al. (2014), we also examined the substantial elevation in renal KIM-1 and NGAL levels in thimerosal-induced nephrotoxicity. It has been observed that the KIM- 1 and NGAL expressions changed before tubular damage in the kidney and an increase in urea and serum creatinine levels can be linked with the increasing histopathological changes (Luo et al., 2014; Luo et al., 2016). So, the increased levels of KIM-1 and NGAL are indicating severe injuries in renal tissues.

In the present study, thimerosal administration raised the level of inflammatory markers NF- $\kappa B, T N F-\alpha$, IL-1 $\beta$, IL-6, and COX-2 activities in treated rats. NF- $\kappa B$ activation is fundamental in the expression of proinflammatory cytokines like NF- $\kappa B$, TNF- $\alpha$, IL-1 $\beta$, IL- 6 and COX-2 that are concerned with acute inflammatory responses and other disorders linked with elevated ROS production (Rehman et al., 2014; Nafees et al., 2015). COX-2 is an inductive form of COX and an additional critical inflammation marker, which plays an important biological role in inflammation (Subbaramaiah and Dannenberg, 2003). In this analysis, the activity of COX-2 was increased in kidney tissues of thimerosal treated groups. Toxicants are associated with increased levels of pro-inflammatory cytokines, such as IL-1 $\beta$ and IL-6 (Salama et al., 2016). In line with these studies, the present work confirmed that the thimerosal treated group showed significant elevation of pro-inflammatory cytokines, including NF- $\kappa \mathrm{B}, \mathrm{TNF}-\alpha$, IL-1 $\beta$, IL-6, and COX-2 when compared to the normal control group. These results solidify the inflammatory role of thimerosal on renal tissues.

Histological study of kidneys showed that thimerosal induced some tubular dilation and focal epithelial cell destruction throughout restricted areas in the cortex. At the same time, in the outer medulla, it persuaded chronic and marked reduction in epithelial cells. Capillaries interacted with tubules were dilated and dilation of tubules was also observed in the inner medulla. Animals treated with thimerosal showed damage in tissues in the form of tubular dilation and lesions, which is in line with a previous study conducted on testicular tissues by Ijaz et al. (2020). Augmented KIM-1 and NGAL levels also endorse histopathological damages. Moreover, increased inflammation or oxidative stress may also be a reason behind the escalated histopathological damage. 


\section{Conclusion}

In conclusion, our results showed thimerosal can cause noticeable oxidative stress. Besides, it decreased the activities of antioxidant enzymes, increased renal inflammation, and incited DNA damage and histopathological alterations. So, it is suggested that it is time to introduce a suitable alternate of thimerosal.

\section{Acknowledgements}

The authors (SM and KAG) express their sincere appreciation to the Researchers Supporting Project Number (2021/24) King Saud University, Riyadh, Saudi Arabia”.

\section{References}

AITKEN, R.J. and ROMAN, S.D., 2008. Antioxidant systems and oxidative stress in the testes. Oxidative Medicine and Cellular Longevity, vol. 1, pp. 15-24.

ARJUMAND, W., SETH, A. and SULTANA, S., 2011. Rutin attenuates cisplatin induced renal inflammation and apoptosis by reducing NFkB, TNF-a and caspase-3 expression in wistar rats. Food and Chemical Toxicology, vol. 49, pp. 2013-2021.

AU, W.W., SALAMA, S.A. and SIERRA-TORRES, C.H., 2003. Functional characterization of polymorphisms in DNA repair genes using cytogenetic challenge assays. Environmental Health Perspectives, vol. 111, pp. 1843-1850.

AYDIN, B., UNSAL, M., SEKEROGLU, Z.A. and GÜLBAHAR, Y., 2011. The antioxidant and antigenotoxic effects of Pycnogenol ${ }^{\circledR}$ on rats treated with cisplatin. Biological Trace Element Research, vol. 142, pp. 638-650.

BALL, L.K., BALL, R. and PRATT, R.D., 2001. An assessment of thimerosal use in childhood vaccines. Pediatrics, vol. 107, pp. 1147-1154.

BERLIN, M., ZALUPS, R.K. and FOWLER, B.A., 2007. Mercury. In: G.F. NORDBERG, B.A. FOWLER, M. NORDBERG and L.T. FRIBERG, eds. Handbook on the Toxicology of Metals. 3rd ed. Chap. 33. New York: Elsevier.

BJøRKLUND, G., DADAR, M., MUTTER, J. and AASETH, J., 2017. The toxicology of mercury: current research and emerging trends. Environmental Research, vol. 159, pp. 545-554.

BURBACHER, T.M., CHARLESTON, L.B. and CHARLESTON, J., 2014. A comparative study of thimerosal in vaccines with methylmercury in a nonhuman primate model. Neurotoxicology and Teratology, vol. 43, pp. 91.

CARLBERG, I. and MANNERVIK, E., 1975. Glutathione level in rat brain. The Journal of Biological Chemistry, vol. 250, pp. 4475-4480.

CEBULSKA-WASILEWSKA, A., PANEK, A., ŻABIŃSKI, Z., MOSZCZYŃSKI, P. and AU, W.W., 2005. Occupational exposure to mercury vapor on genotoxicity and DNA repair. Mutation Research, vol. 586, pp. 102-114.

CHANCE, B. and MAEHLY, A.C., 1955. Assay of catalase and peroxidases. Methods in Enzymology, vol. 11, pp. 764-755.

COUNTER, S.A. and BUCHANAN, L.H., 2004. Mercury exposure in children: a review. Toxicology and Applied Pharmacology, vol. 198, pp. 209-230.

DE LA TORRE, A., BELLES, M., LLOBET, J.M., MAYAYO, E. and DOMINGO, J.L., 1998. Comparison of the effectiveness of 2 , 3-dimercaptopropanol (BAL) andmeso-2, 3-dimercaptosuccinic acid (DMSA) as protective agents against mercuric chloride- induced nephrotoxicity in rats. Biological Trace Element Research, vol. 63, pp. 1-10.

DEPONTE, M., 2013. Glutathione catalysis and the reaction mechanisms of glutathione-dependent enzymes. $B B A-$ bioenergetics, vol. 5, pp. 3217-3266.

DHAWAN, A., BAJPAYEE, M. and PARMAR, D., 2009. Comet assay: a reliable tool for the assessment of DNA damage in different models. Cell Biology and Toxicology, vol. 25, pp. 5-32.

DÓREA, J.G., FARINA, M. and ROCHA, J.B., 2013. Toxicity of ethylmercury (and Thimerosal): a comparison with methylmercury. Journal of Applied Toxicology, vol. 33, no. 8, pp. 700-711.

EKAWANTI, A. and KRISNAYANTI, B.D., 2015. Effect of mercury exposure on renal function and hematological parameters among artisanal and small-scale gold miners at Sekotong, West Lombok, Indonesia. Journal of Health and Pollution, vol. 5, pp. 25-32.

EKE, D. and CELIK, A., 2008. Genotoxicity of thimerosal in cultured human lymphocytes with and without metabolic activation sister chromatid exchange analysis proliferation index and mitotic index. Toxicology In Vitro, vol. 22, pp. 927-934.

ERCAL, N., GURER-ORHAN, H. and AYKIN-BURNS, N., 2001. Toxic metals and oxidative stress part I: mechanisms involved in metal-induced oxidative damage. Current Topics in Medicinal Chemistry, vol. 1, no. 6, pp. 529-539.

HERMAN, L.M., GERBERT, D.A., LARSON, L.W., LÉGER, M.M., MCNELLIS, R., O'DONOGHUE, D.L., ULSHAFER, C. and VAN DYKE, E.M., 2006. Vaccines, thimerosal, and neurodevelopmental outcomes. JAAPA: Official Journal of the American Academy of Physician Assistants, vol. 19, pp. 16-18.

IBRAHIM, K.E., AL-MUTARY, M.G., BAKHIET, A.O. and KHAN, H.A., 2018. Histopathology of the liver, kidney, and spleen of mice exposed to gold nanoparticles. Molecules (Basel, Switzerland), vol. 23, no. 8, pp. 1848.

IJAZ, M.U., BATOOL, M., ASHRAF, A., SIDDIQUE, M.H., ZAFAR, S., MUZZAMIL, S., AYAZ, F., SAMAD, A., AL-GHANIM, K. and MAHBOOB, S., 2020. A study on the Potential reprotoxic effects of thimerosal in male albino rats. Saudi Journal of Biological Sciences. http://dx.doi.org/10.1016/j.sjbs.2020.06.045.

QBAL, M., SHARMA, S.D., REZAZADEH, H., HASAN, N., ABDULLA, M. and ATHAR, M.J.R.R., 1996. Glutathione metabolizing enzymes and oxidative stress in ferric nitrilotriacetate mediated hepatic injury. Redox Report, vol. 2, pp. 385-391.

JOLLOW, D., MITCHELL, J., ZAMPAGLIONE, N.A. and GILLETTE, J., 1974. Bromobenzene-induced liver necrosis. Protective role of glutathione and evidence for 3, 4- bromobenzene oxide as the hepatotoxic metabolite. Pharmacology, vol. 11, pp. 151-169.

KAKKAR, P., DAS, B. and VISWANATHAN, P.N., 1948. A modified spectrophotometric assay of superoxide dismutase. Indian Journal of Biochemistry \& Biophysics, vol. 21, pp. 130-132.

KAMIANOWSKA, M., SZCZEPAŃSKI, M. and WASILEWSKA, A., 2019. Tubular and Glomerular Biomarkers of Acute Kidney Injury in Newborns. Current Drug Metabolism, vol. 20, pp. 332-349.

KANEKO, T., IUCHI, Y., KOBAYASHI, T., FUJII, T., SAITO, H., KURACHI, H. and FUJII, J., 2002. The expression of glutathione reductase in the male reproductive system of rats supports the enzymatic basis of glutathione function in spermatogenesis. European Journal of Biochemistry, vol. 269, pp. 1570-1578.

KHAN, R., KHAN, A.Q., QAMAR, W., LATEEF, A., ALI, F., REHMAN, M.U., TAHIR, M., SHARMA, S. and SULTANA, S., 2012. Chrysin abrogates cisplatin-induced oxidative stress, p53 expression, goblet cell disintegration and apoptotic responses in the jejunum of Wistar rats. British Journal of Nutrition, vol. 108, pp. 1574-1585. 
KHAN, R.A., KHAN, M.R., SAHREEN, S. and BOKHARI, J., 2010. Prevention of CCl4-induced nephrotoxicity with Sonchus asper in rat. Food and Chemical Toxicology, vol. 48, pp. 2469-2476.

LEI, L., LI, L.P., ZENG, Z., MU, J.X., YANG, X., ZHOU, C., WANG, Z.L. and ZHANG, H., 2018. Value of urinary KIM-1 and NGAL combined with serum Cys $\mathrm{C}$ for predicting acute kidney injury secondary to decompensated cirrhosis. Scientific Reports, vol. 8, pp. 1-9.

LIOCHEV, S.I. and FRIDOVICH, I., 2010. Mechanism of the peroxidase activity of $\mathrm{Cu}, \mathrm{Zn}$ superoxide dismutase. Free Radical Biology $\mathcal{E}$ Medicine, vol. 48, pp. 1565-1569.

LOBO, V., PATIL, A., PHATAK, A. and CHANDRA, N., 2010. Free radicals, antioxidants and functional foods: impact on human health. Pharmacognosy Reviews, vol. 4, no. 8, pp. 118-126.

LOWRY, O.H., ROSEBROUGH, N.J., FARR, A.L. and RANDALL, R.J., 1951. Protein measurement with the Folin phenol reagent. The Journal of Biological Chemistry, vol. 193, pp. 265-275.

LU, Y., LIU, Y. and YANG, C., 2017. Evaluating in vitro DNA damage using comet assay. JoVE, vol. 128, pp. 56450.

LUO, Q.H., CHEN, M.L., CHEN, Z.L., HUANG, C., CHENG, A.C., FANG, J., TANG, L. and GENG, Y., 2016. Evaluation of KIM-1 and NGAL as early indicators for assessment of gentamycin-induced nephrotoxicity in vivo and in vitro. Kidney $\&$ Blood Pressure Research, vol. 41, pp. 911-918.

LUO, Q.H., CHEN, M.L., SUN, F.J., CHEN, Z.L., LI, M.Y., ZENG, W., GONG, L., CHENG, A.C., PENG, X., FANG, J. and TANG, L., 2014. KIM-1 and NGAL as biomarkers of nephrotoxicity induced by gentamicin in rats. Molecular and Cellular Biochemistry, vol. 397, pp. 53-60.

MAHBOOB, M., SHIREEN, K.F., ATKINSON, A. and KHAN, A.T., 2001. Lipid peroxidation and antioxidant enzyme activity in different organs of mice exposed to low level of mercury. Journal of Environmental Science and Health. Part. B, Pesticides, Food Contaminants, and Agricultural Wastes, vol. 36, pp. 687-697.

MORI, K., LEE, H.T., RAPOPORT, D., DREXLER, I.R., FOSTER, K., YANG, J., SCHMIDT-OTT, K.M., CHEN, X., LI, J.Y., WEISS, S. and MISHRA, J., 2005. Endocytic delivery of lipocalin-siderophoreiron complex rescues the kidney from ischemia-reperfusion injury. The Journal of Clinical Investigation, vol. 115, pp. 610-621.

NABIL, A., ELSHEMY, M.M., ASEM, M. and GOMAA, H.F., 2020. Protective Effect of DPPD on Mercury Chloride-Induced Hepatorenal Toxicity in Rats. Journal of Toxicology, vol. 2020, pp. 1-7.

NAFEES, S., RASHID, S., ALI, N., HASAN, S.K. and SULTANA, S., 2015. Rutin ameliorates cyclophosphamide induced oxidative stress and inflammation in Wistar rats: role of NFKB/MAPK pathway. Chemico-Biological Interactions, vol. 231, pp. 98-107.

PARK, J.D. and ZHENG, W., 2012. Human exposure and health effects of inorganic and elemental mercury. Journal of Preventive Medicine and Public Health, vol. 45, no. 6, pp. 344.

PICK, E. and KEISARI, Y., 1981. Superoxide anion and hydrogen peroxide production by chemically elicited peritoneal macrophages-induction by multiple nonphagocytic stimuli. Cellular Immunology, vol. 59, pp. 301-318.
REHMAN, M.U., ALI, N., RASHID, S., JAIN, T., NAFEES, S., TAHIR, M., KHAN, A.Q., LATEEF, A., KHAN, R., HAMIZA, O.O. and KAZIM, S., 2014. Alleviation of hepatic injury by chrysin in cisplatin administered rats: probable role of oxidative and inflammatory markers. Pharmacological Reports, vol. 66, pp. 1050-1059.

ROSS, J.A. and KASUM, C.M., 2002. Dietary flavonoids: bioavailability, metabolic effects, and safety. Revista de Nutrição, vol. 22, pp. 19-34.

SALAMA, S.A., ARAB, H.H., MAGHRABI, I.A., HASSAN, M.H. and ALSAEED, M.S., 2016. Gamma-glutamyl cysteine attenuates tissue damage and enhances tissue regeneration in a rat model of lead-induced nephrotoxicity. Biological Trace Element Research, vol. 173, pp. 96-107.

SALEH, R.A. and AGARWAL, A., 2002. Oxidative stress and male infertility: from the research bench to clinical practice. Journal of Andrology, vol. 23, pp. 737-752.

SHARAF, S., KHAN, M.U., ASLAM, A. and RABBANI, M., 2020. Comparative study of heavy metals residues and histopathological alterations in large ruminants from selected areas around industrial waste drain. Pakistan Veterinary Journal, vol. 40, no. 1, pp. 55-60.

SHIN, E.K., KWON, H.S., KIM, Y.H., SHIN, H.K. and KIM, J.K., 2009. Chrysin, a natural flavone, improves murine inflammatory bowel diseases. Biochemical and Biophysical Research Communications, vol. 381, pp. 502-507.

SUBBARAMAIAH, K. and DANNENBERG, A.J., 2003. Cyclooxygenase 2: a molecular target for cancer prevention and treatment. Trends in Pharmacological Sciences, vol. 24, pp. 96-102.

TAN, M. and PARKIN, J.E., 2000. Route of decomposition of thiomersal (thimerosal). International Journal of Pharmaceutics, vol. 208, pp. 23-34.

TRÜMPLER, S., LOHMANN, W., MEERMANN, B., BUSCHER, W., SPERLING, M. and KARST, U., 2009. Interaction of thimerosal with proteins: ethylmercury adduct formation of human serum albumin and $\beta$-lactoglobulin A. Metallomics, vol. 1, pp. 87-91.

VIMERCATI, L., SANTARELLI, L., PESOLA, G., DRAGO, I., LASORSA, G., VALENTINO, M., VACCA, A. and SOLEO, L., 2001. Monocytemacrophage system and polymorphonuclear leukocytes in workers exposed to low levels of metallic mercury. The Science of the Total Environment, vol. 270, pp. 157-163.

YEL, L., BROWN, L.E., SU, K., GOLLAPUDI, S. and GUPTA, S., 2005. Thimerosal induces neuronal cell apoptosis by causing cytochrome $\mathrm{c}$ and apoptosis-inducing factor release from mitochondria. International Journal of Molecular Medicine, vol. 16, pp. 971-977.

ZALUPS, R.K. and DIAMOND, G.L., 1987. Mercuric chloride-induced nephrotoxicity in the rat following unilateral nephrectomy and compensatory renal growth. Virchows Archiv. B, Cell Pathology Including Molecular Pathology, vol. 53, pp. 336.

ZHOU, Y., VAIDYA, V.S., BROWN, R.P., ZHANG, J., ROSENZWEIG, B.A., THOMPSON, K.L., MILLER, T.J., BONVENTRE, J.V. and GOERING, P.L., 2008. Comparison of kidney injury molecule-1 and other nephrotoxicity biomarkers in urine and kidney following acute exposure to gentamicin, mercury, and chromium. Toxicological Sciences, vol. 101, pp. 159-170. 